\title{
Marketing Communication Based Local Wisdom on Micro, Small, and Medium Enterprises During Pandemic Covid 19
}

\author{
Mutiah $^{1, *}$ Vinda Maya Setianingrum ${ }^{2}$ Anam Miftakhul Huda ${ }^{3}$ \\ 1,2,3 Universitas Negeri Surabaya
}

*Corresponding author.Email: Mutiah@ unesa.ac.id

\begin{abstract}
The condition of COVID-19 pandemic has changed the pattern of human life from various aspects, one of them is the most affected by the economic aspect of the community. The wheels of the community's economy are hampered due to the policy of implementing restrictions on community activities (PPKM) in several regions in Indonesia. Micro, small and medium business activities are experiencing difficulties in the distribution and sales sectors to capital, but the community is trying to get up and survive during the pandemic. Marketing communication activities by prioritizing local wisdom are important to be studied and researched further, in order to become a reference for marketing models during the pandemic for people engaged in the micro business sector in general. From the results of the interview, it is obtained a description of the marketing communication of micro, small and medium business actors. There are two conditions, namely marketing communication through online media and traditional methods. The conclusion of this article is that marketing communications for micro, small and medium enterprises in the midst of a pandemic can rise because there are activities based on local wisdom that are put forward by the community and business actors themselves. The difficult pandemic period for small business actors will feel lighter if all people are aware of supporting each other so that small businesses can run their businesses productively.
\end{abstract}

Keywords: Marketing Communication, Local Wisdom, Micro, Small and Medium Enterprises

\section{INTRODUCTION.}

The implementation of restrictions on community activities (PPKM) during the COVID-19 pandemic in Java and Bali regions in Indonesia has had quite a detrimental impact on every aspect, especially the economic aspect. The economic activity of the residents has decreased, coupled with the low purchasing power of the people due to a decrease in income [1]. Business actors, micro, small and medium, are among the community business actors who are quite affected. In fact, micro, small and medium enterprises are one of the main pillars of Indonesia's economic fundamentals [2]. Most of the micro, small and medium enterprises are the lowerclass economic community with limited business capital, therefore micro, small and medium enterprises are very dependent on the people's purchasing power, but the purchasing power of the people during the pandemic is weak due to the decline in income. This condition allows micro, small and medium enterprises to reduce the amount of production or even stop production and distribution. According to the Katadata 
Insight Center (KIC) micro, small and medium enterprises experienced a negative impact of $82.9 \%$ and only $5.9 \%$ experienced growth during the pandemic [3]. The imposition of restrictions on community activities has caused traditional buying and selling activities to decline as a negative impact of the COVID-19 pandemic, thus requiring micro, small and medium enterprises to adapt and implement appropriate marketing communication strategies. Marketing communication is a planning concept by examining the strategic role of other forms of communication [4]. In practice IMC the central idea is that communicationdoes not take places in a vacuum [5]. Marketing communication is a very broad activity for example- advertising, direct selling, promotion, and other activities

Marketing communication is an element of the marketing mix [5], this concept can be adopted by business actors one type of marketing communication that is usually carried out by small business actors is direct selling and relies on words of mouth promotion. Although this method is generally quite successful, with the current pandemic conditions, business actors must choose an alternative, so the online sales method is an option. The activity of communicating business onlineto potential markets must be done to reach a wider market. Online product promotions can be an option to reach awareness for potential consumers, awareness of business actors to promote products starting with branding their products. A trademark is a name or product identity, according to Miller, choosing a brand name is one of the most important business decisions you will make a brilliant name defines your brand, and it can shape the future of your business.

Although most of the micro, small and medium enterprises have tried to implement several online marketing strategies, not all of them are able to take advantage of the available marketplace or online marketing platform. With limited internet access capabilities and the operation of internet-based technology. Some of these business actors still survive by traditional marketing methods. Groups of the micro, small and medium enterprises that carry out conventional marketing are full of Indonesian cultural values which become local wisdom. Local wisdom is a basic idea or view of life about the balance of life and nature, which is continuously passed down from generation to generation as a way of life in society. Gotong royong is a movement to help, support and care for one anothers [6]. Small business actors are well aware that with care, involvement and working hand in hand in their communities, they can survive in the midstof a pandemic. Although their business has not provided the same benefits as before, with the support from relatives, friends and the environment, it is possible for the community around micro, small and medium enterprises have the enthusiasm to run their business. In marketing communication, the value of gotong royong can occur in the type of personal selling. Personal selling is a form of marketing with direct meetings between sellers and buyers. The seller explores the buyer and makes a decision to buy the goods or servicesoffered. Communication in personal selling is done directly so that it is more persuasive to potential consumers [7].

This article wants to see the marketing communications carried out by micro, small and medium enterprises with minimal capital in the midst of a pandemic based on local wisdom. Local wisdom can be in the form of culture, customary values in the community, both clearly and implicitly. The nuance of local wisdom becomes a distinctive character value that cannot be separated from the marketing activities ofsmall business groups.

\section{METHODS}

This study uses a qualitative approach, in order to find and describe a narative way the activities carried out and the impact of the actions taken on their lives this research data is presented descriptively [8]. research data in the form of interviews. Research informants are micro, small and medium enterprises. there are 4 informants in this study. The following are the informants in this research

Table 1. Research Informants

\begin{tabular}{|l|l|l|}
\hline No & Name (Informant's Initials) & Kind of products \\
\hline 1. & AH (@Buknengfood) & Foods \\
\hline 2 & FG (@ Kopibudaya) & Beverage \\
\hline 3. & AS (@ makememine) & Accessories \\
\hline 4. & LK & Handycraft \\
\hline
\end{tabular}

\section{RESULTS AND DISCUSSION}

\subsection{Marketing Communications For Micro, Small and Medium Businesses In The Time of The Covid-19 Pandemic}

Micro, small and medium enterprises are the sectors that have been hit hard during the pandemic. Micro, small and medium enterprises experienced a decrease in purchases, reduced capital and hampered distribution[9]. The weakness of this sector brought a decline in the national economy. However, business actors, micro, small and medium enterprises are still trying to get up and run their businesses. There are two conditions for business actors, micro, small and medium, namely groups of people who have been running this business for a long time and experienced negative impacts from 
the COVID-19 pandemic but there are just starting to become business actors, micro, small and medium because of termination of employment from their employer the company they worked before.

The condition of community groups who are just starting a business during the pandemic is more difficult because they have to start looking for new customers, while at that time people's purchasing power in general decreases. On the other hand, the presence of new players for business, micro, small and medium for groups of people who have been running small businesses for a long time is a new competitor that is increasingly tightening market competition. The increasingly strong competition in the pandemic conditions, of course, requires these business actors to work hard in communicating their products to the market. To seize the market for several business actors, micro, small and medium enterprises using social media or marketplace platforms, selling products using online media is very important because during the COVID-19 pandemic, market conditions are quiet [10]. Some othersstill rely on traditional methods and minimal use ofonline media.

Both those who do marketing through marketplace platforms and social media as well as directly offer product promotions to encourage consumers to buy on the spot. The type of promotion that is most often carried out by these business actors is to provide price discounts or short-term discounts. In addition, business actors who still sell in the traditional way open merchandise outlets early. This method is considered capable of inviting consumers to make their first purchase. As did the culinary business Bukneng Food. This business owner admits that during the pandemic, sales have decreased quite drastically. Here's an excerpt from the interview

"For sales during the pandemic, it has decreased drastically, but all Business, Micro, Small and Medium Enterprises are experiencing the same thing. My strategy is to provide price discounts or promos, sobuyers are interested and want to try my products."

From the statement of the owner of Bukneng Food, it can be seen that the pandemic has had a drastic impact on all small business actors. However, they did not stop their business activities but implemented more strategies to attract buyers. Promotions and price discounts for Bukneng Food's products were also conveyed via Instagram as social media. Instagram has an advantage in the aspect of higher interactivity than Facebook or Twitter. Instagram provides 15 times higher engagement than Facebook and Twitter [10].

So choosing to post products and do sales promotions on Instagram is the right choice. Promoting products through social media is the choice of almost all business actors, micro, small and medium because it is considered more efficient and effective in reaching the target audience. Business actors who have just started their business also rely on social media to introduce their products. The pandemic conditions and government policies limit people's activities so that they do not allow them to conduct direct sales. The following is a promotional image of product price discounts from Bukneng Food:

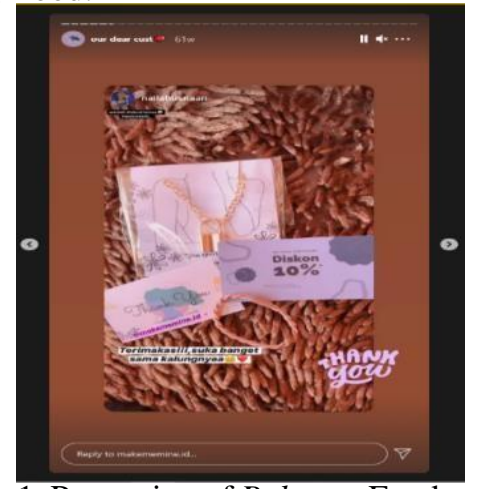

Figure 1. Promotion of Bukneng Food on Social Media

Different conditions experienced by OC business the actors, the initial business he had done had to be forced to close because sales decreased drastically during the pandemic. But OC actually started a new, different business. New product development is not an easy thing because new product development is the complete process of bringing a new product to the market [11]. According to the $\mathrm{OC}$, businesses that have just restarted are more representative for young people. OC sells cosmetics and some women's accessories, named @ makememine. This business actor also chooses to do more online sales, through his social media, namely Instagram. Instagram can be called the favorite social media for the millennial generation in Indonesia [12]. The business that he just started back during the pandemic was actually quite accepted by his potential consumers. One way to attract attention is to use sales promotions, namely rebates and discounts. According to OC, this method can increase sales quickly. The following is a picture of the product

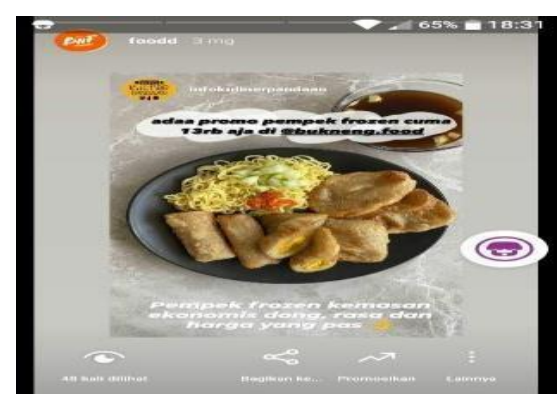

Figure 2. Discounts for @makememine products on Instagram 
Many businesses, micro, small and medium-sized enterprises choose to be more active in selling online, but some continue to sell directly because they have already rented a place of business. This is experienced by coffee shop entrepreneurs. Before the "cangkruk" culture pandemic, the people of East Java brought their own blessings to coffee shop business actors, and the "Cultural Coffee" shop was no exception. The "Kopi Budaya" shop was founded by young people. With minimal capital, these young people find it impossible to close their businesses despite the government's policyof restricting community activities. The way they do is opening and closing system and take away services.

This shop opening and closing system is adjusted to government regulations. In line with the policy that allows people to eat and drink at the point of sale, this shop has also opened its service longer. However, the coffee shop which they manage is still experiencing a drastic decline in sales. Their strategy to survive is to promote to loyal customers. This coffee shop already has customers marked with a membership card. Loyal card is the name of the customer card that they issue,this card is their mainstay to retain customers. Through the membership card, the team provides promotions via WhatsApp to their customers'. In addition to sales promotions, the unique thing they do is provideeducation about Indonesian cultures through Instagram posts.

The manager of "Kopi Budaya" shop prefers to promote more often to loyal customers than to find new customers. According to them, during the pandemic, it is better to focus on retaining customers than to focus on finding new customers. Keeping new customers is more effective because the effort they spend is not too big amid the lack of profit from sales during the pandemic. Here's a picture of the product from "Coffee Culture"
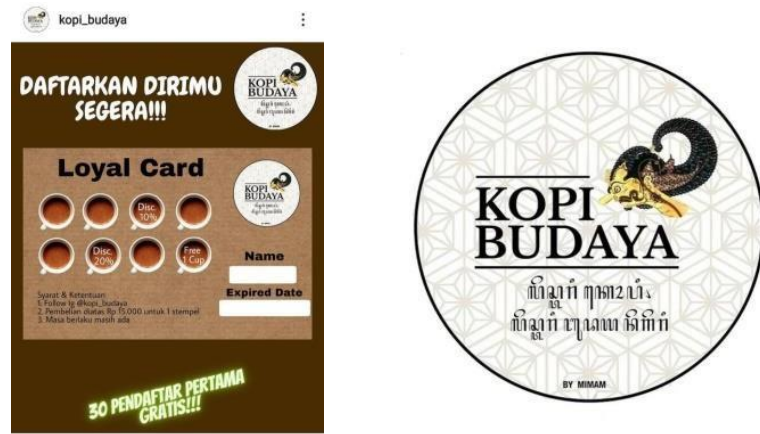

Figure 3. logos and examples of customer cards Direct

selling activities are not only carried out by business actors who have rented a place, but also business actors due to limitations in selling through the marketplace. This business actor is engaged in handicrafts, making knitted bags from wool yarn. The business owner, Mrs. L, is a member of a group of the micro, small and medium enterprises in Taman Sidoarjo District. During the pandemic he peddled his handicrafts among business members, micro, small and medium in Taman District. In addition, it also offers sales to relatives and neighbors. The following are handicraft products from woolen yarn developed by Ms. L

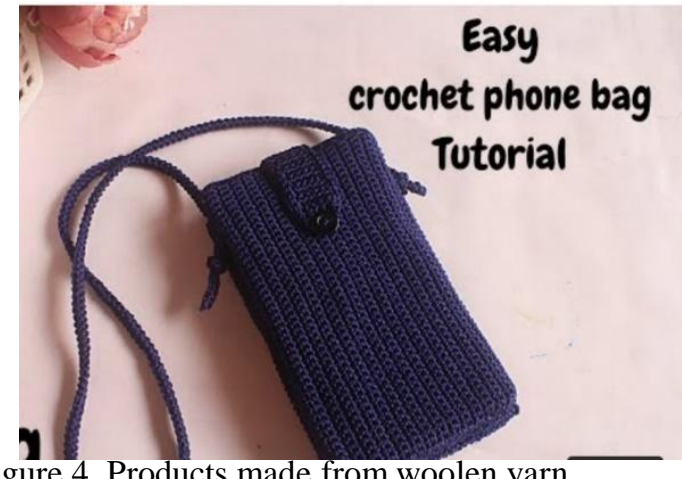

The impact of the pandemic on business owners is quite large, especially in the aspect of government policies that limit people's movement. Before the pandemic, Ms. L, as a developer of wool handicrafts, often participated in trade fairs

Both on a local and national scale, but since the pandemic these activities have changed in virtual form. The format of the virtual exhibition was not familiar to Mrs. L, that's why Ms. L's sales relied on traditional methods, direct sales and word of mouth promotions as well as through WhatsApp messages.

\subsection{Marketing Communications for Micro, Small and Medium Enterprises Based on Local Wisdom}

Every society in a certain area have certain cultures and habits. Indonesian people are known to have a variety of unique cultures, this culture is passed down from generation to generation so that it becomes local wisdom because it contains noble values that are adhered to and attached to the community. We can see this noble value through the traditions that are carried out, both traditions that are celebratory in nature and traditions that have become the habits of the community. Local wisdom contains values that can be a means of building national character [13].

The condition of the COVID-19 pandemic has indeed given many changes, it is undeniable that the negative impact is a decrease in sales for business actors, micro, small and medium enterprises. But on the other hand, the pandemic condition is an opportunity for business actors to expand their market reach by utilizing technology and online networks. Business actors can use the marketplace, social media and other marketing platforms. Online marketing strategies are welcomed by 
millennial or Generation $\mathrm{Z}$ business actors who are indeed adaptive to technological changes, but not all can easily use online methods to sell their business products. So there are still many entrepreneurs who use conventional methods. In a situation where people's activities are restricted, and people's purchasing power is declining, conventional selling is not easy, but closing a business is also not a wise choice.

Business actors, micro, small and medium, both those who do traditional marketing and use online media, both still do not abandon local cultural values in their product marketing activities. The culture of gotong royong, caring for each other in fact means a lot to these business actors, in the midst of their difficulties running a business and decreasing income in the midst of the COVID-19 pandemic. Gotong royong and caring foreach other can be seen from buying and selling activities. Fellow business actors buy each other's wares and promote the wares of each other. These efforts to work hand in hand are more important than measuring the competitiveness of business actors. In addition, product buyers from business actors, micro, small and medium enterprises are dominated by relatives, other small business actors, the surrounding community, friends and relatives. They buy products from business actors, micro, small and medium because they want to help so that their business does not stop due to lack of capital, besides the movement to buy small business products as a form of support so that the actors have enthusiasm and are productive.

For small business actors, promoting each other is a form of mutual support and fostering enthusiasm in the midst of the economic downturn during the pandemic. This noble value of gotong royong is a national character that must be preserved. The following is a marketing model based on local wisdom that the author collects from interviews and observations of Micro, Small and Medium Enterprises in several areas in East Java.
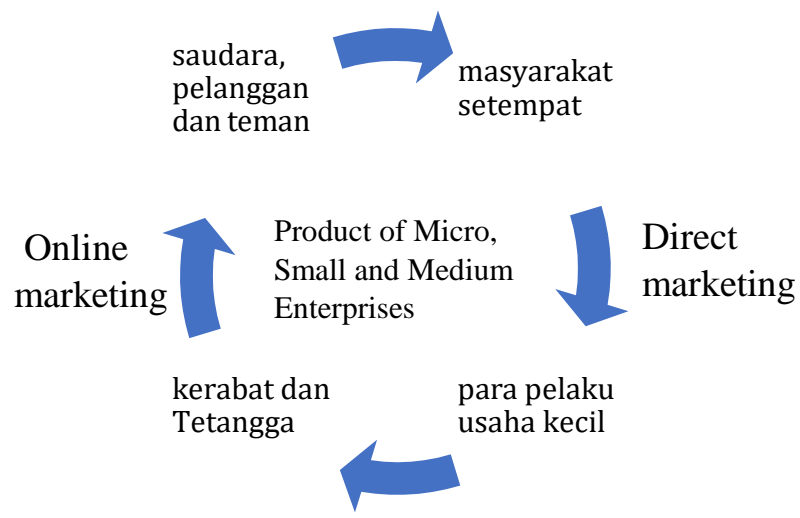

Figure 5. Marketing activity pattern of Micro, Small and Medium
Small and Medium Enterprises, both through online and direct marketing, show that buying and selling activities revolve in a circle of social closeness. This circle of social closeness is their own friends, customers, among the small business actors themselves, relatives and neighbors. There is a culture of gotong royong, work together and a sense of caring that underlies them to buy products from small business actors because they are aware that in the midst of a pandemic, mutual support must be done so that affected small business actors rise up and the wheels of the economy move to help the recovery of the national economy.

\section{CONCLUSION}

Marketing communications carried out by micro, small and medium enterprises are in two conditions, namely through online media and through direct marketing. Direct marketing strategy relies on words of mouth communication and maintaining good relationships with customers in the social relationship circle. In marketing communication activities, micro, small and medium enterprises are influenced by the nuances of local wisdom. The community adheres to a culture of mutual assistance, mutual support, mutual care which is the biggest motivation in purchasing products from micro, small and medium enterprises. This local wisdom-based marketing communication activity is able to increase the confidence of small business actors to run their businesses amidst the difficulties they face during the COVID-19 pandemic.

\section{ACKNOWLEDGMENT}

I would like to express my sincere gratitude to the members of micro, small and medium enterprises especially the owner of bukneng food, makememine and kopi budaya. This research work would not be possible without hit stimulation, inspiration and cooperation

\section{REFERENCES}

[1] A. Halimatussadiah et al., Thinking Ahead: Indonesia's Agenda on Sustainable Recovery from COVID -19 Pandemic. 2020.

[2] B. Arianto, "Pengembangan UMKM Digital di Masa Pandemi Covid-19," ATRABIS J. Adm. Bisnis, vol. 6, no. 2, pp. 233-247, 2020,[Online]. Available:

https://www.jurnal.plb.ac.id/index.php/atrabis/ar ticle/view/512.

R. A. Bahtiar, "Dampak Pandemi Covid-19

Terhadap Sektor Usaha Mikro, Kecil, dan Menengah Serta Solusinya," Pus. Penelit. Badan Keahlian DPR RI, Bid. Ekon. Dan Kebijak. Publik, vol. XIII, no. 10, pp. 19-24, 
2021, [Online]. Available: https://berkas.dpr.go.id/puslit/files/info_singkat/ Info Singkat-XIII-10-II-P3DI-Mei-20211982.pdf.

[4] A. Hermawan, Komunikasi Pemasaran. Jakarta: Erlangga, 2012.

[5] A. S. Terence, Integrated Marketing Communication in Advertising and Promotion. Jakarta: Salemba, 2010.

[6] D. Kartikawangi, "Kearifan Lokal dalam Implementasi Cause Related Marketing untuk Keberlanjutan Bisnis," J. ASPIKOM, vol. 3, no. 5, p. $874, \quad 2018, \quad$ doi: 10.24329/aspikom.v3i5.278.

[7] S. Kusniadji, "Kontribusi Penggunaan Personal Selling Dalam Kegiatan Komunikasi Pemasaran Pada Era Pemasaran Masa Kini,” J. Komun., vol. 9, no. 2, p. 176, 2018, doi: 10.24912/jk.v9i2.1078.

[8] Sugiyono, Metode Penelitian Kualitatif dan $R$ $\& D$. Bandung: Alfabeta, 2015.

[9] A. Amri, "Pengaruh Periklanan Melalui Media Sosial Terhadap UMKM di Indonesia di Masa PAndemi," J. Brand, vol. 2, no. 1, pp. 123-130, 2020, [Online]. Available: https://www.academia.edu/42672824/Dampak_ Covid-19_Terhadap_UMKM_di_Indonesia.

[10] Nurdina, M. R. Ardhiani, C. M. S. Handayani, and F. Asj' ari, "Strategi Pemberdayaan UMKM Makanan Berbasis Kearifan Lokal Di Masa Pandemi Covid-19 Di Desa Slempit Kedamean Gresik," Ekobis Abdimas, vol. 2, no. 1, pp. 4351, 2021.

[11] M. Suwannaporn, P., \& Speece, "Continuous learning process in new product development in the Thai food-processing industry," Br. Food J., 2000.

[12] L. W. Evelina and F. Handayani, "Penggunaan Digital Influencer dalam Promosi Produk (Studi Kasus Akun Instagram @bylizzieparra),"War. ISKI, vol. 1, no. 01, p. 71, 2018, doi: 10.25008/wartaiski.v1i01.10.

[13] T. Tarmizi and I. Ismail, "Model Marketplace Berbasis Kearifan Lokal," J. EMT KITA, vol. 4, no. 1, p. 11, 2020, doi: 10.35870/emt.v4i1.125. 